\title{
Patterns of Urediospore Movement and Monitoring Epidemics of Stem Rust (Puccinia graminis f.sp.tritici) on Durum Wheat in Southeastern Ethiopia
}

\author{
Kebede Tadesse* and Bekele Hundie
}

Oromia Agricultural Research Institute, Sinana Agricultural Research Center, P O Box 208, Bale Robe, Ethiopia

\begin{abstract}
Stem rust caused by Puccinia graminis f.sp.tritici is a significant wheat production constraint in southeastern Ethiopia. Burkard 7-days volumetric spore trap was mounted in a field at Sinana Agricultural Research Center to examine the seasonal movement of urediospores of $P$. graminis f.sp.tritici during the cropping seasons of 2001-2006. Disease trap plots were also established to monitor the epidemics of stem rust on durum wheat at three major wheat growing and rust prone districts of Bale highlands viz., Sinana, Agarfa and Herero. Results showed that urediospores exist in the air throughout the year though the concentration considerably varied among the months and seasons, possibly because of the variation in weather condition and cropping time. The highest urediospores catch (613.8 - 2629.7 urediospores per $\mathrm{m}^{3}$ of air) was observed during the months of October/November-January. Number of urediospores per $\mathrm{m}^{3}$ of air was generally low but was rarely reduced to zero during the months of crop free period. Low to moderate levels of stem rust epidemics (not exceeding $30 \%$ ) were recorded on durum wheat cultivars used for traps. Exceptions were at Sinana in 2001 and at Herero in 2002 and 2005 cropping seasons during which up to $60 \%$ stem rust severity levels were recorded. On the other hand, the level of stem rust severity (up to $80 \%$ ) on some commercial bread wheat varieties included in this study for comparison revealed the development of high disease pressure. Durum wheat cultivars Cocorit 71, Gerardo, DZ 1928-2, DZ-2234 and CD 95759-11M showed resistant reaction to stem rust consistently over locations and years. This points to the existence of a high level of durable resistance in the tetraploid wheat species to the existing stem rust pathotypes in the most suitable environment for the development of the disease.
\end{abstract}

Keywords: Durum Wheat; Epidemics; Stem Rust; Urediospores

\section{Introduction}

Cereal rusts are the most destructive diseases of wheat worldwide (Shaw, 1963; Haldore et al., 1982). Stem rust, also known as black rust caused by the fungus Puccinia graminis f.sp.tritici Eriks, and E. Henn, is the most significant of all wheat diseases under favorable conditions. Ethiopia is one of the hot spot areas for the development of the existing stem rust complex (Leppik, 1970). Invariable epidemics of wheat stem rust have occurred in the major wheat growing areas of Ethiopia. It became a major threat for Ethiopian wheat production after the epidemics of 1974 and 1992/1993 that eliminated bread wheat varieties known as Lacketch and Enkoy from production. Stem rust races prevalent in Ethiopia are among the most virulent races in the world (van Ginkil et al., 1989) with wide virulence spectrum and most frequent change in pathogenecity. This is more commonly observed in Arsi and Bale highlands, which are the wheat belt of eastern Africa.

The use of genetically resistant cultivars has been the major strategy to control wheat stem rust in Ethiopia. Several bread wheat (Triticum aestivum) and durum wheat (Triticum durum) varieties have been released since the commencement of wheat breeding in the country. Many of the high yielding and resistant bread wheat cultivars released at national and regional levels became susceptible to either stem rust or yellow rust or both within a short period after their release for large-scale production (SARC, 2006). These changes in response to disease were associated with inadequate knowledge of the virulence present in the pathogen population and the existence of unsatisfactory durable resistance in major commercial bread wheat cultivars.

*Corresponding author. E-mail: kebedetade@yahoo.com
Durum wheat, on the other hand, has been regarded as one of the major sources of resistance to cereal rusts in Ethiopia (Bekele, 2003; Naod, 2004; Naod et al., 2007). The country is known to be the center of diversity for the tetraploid wheat species, which present high genetic diversity for disease resistance and other merits (Porceddu and Perrino, 1973; Ephrem et al., 2000). Sewalem et al (2000) also reported the existence of stability of stem rust resistance in some durum wheat varieties in the highlands of central Ethiopia. The status of stem rust epidemics on durum wheat in southeastern Ethiopia has not been well reported so far. Currently, durum wheat is widely cultivated in Bale highlands, replacing the introduced semi-dwarf bread wheat cultivars. Such a shift is mainly due to the high risk of rust epidemics on bread wheat and consideration of food complex factories to utilize locally produced durum wheat grains. Stem rust epidemics should, therefore, be monitored regularly to understand the status and shift in the disease situation on durum wheat in the Bale highlands.

Survival of the wheat stem rust fungi through the offseason period is an essential component of the stem rust disease cycle as it is a factor for epidemic persistence and subsequent disease development. Barberry (Berberris vulgaris $L$.) does not occur naturally in the Bale highlands (Sorokina et al., 1980; Zerihun and Abdella, 2000), indicating that teleospores are non-functional. Wheat in this region is grown twice a year, during the main season (August-December) and the second season (March-July). This cereal belt of eastern Africa is also characterized by wheat-based monocropping which presents a green bridge between two succeeding seasons. Epidemic persistence is therefore achieved by successive uredial generations carried from volunteer wheat growing in 
cultivation or on headland. Long-distance transport of urediospores also cannot be overlooked as overlapping in race pattern between Ethiopia and some east African countries exists (Saari and Prescott, 1985). Determining the pattern of seasonal dynamics of the pathogen propagules causing epidemic persistence and disease monitoring in relation to the prevailing weather conditions are essential components for predicting disease epidemics. This study was undertaken to investigate the importance of seasonal pattern and the dynamics of wheat stem rust urediospores as well as to monitor its epidemic on durum wheat cultivars in southeastern Ethiopia.

\section{Materials and Methods}

\subsection{Experimental Sites}

The experiments were conducted at three major wheat growing and rust prone districts of Bale: Sinana Agricultural Research Center (SARC), Agarfa and Herero during the 2001-2006 cropping seasons. The locations represent the highland wheat growing areas of Bale with bimodal rainfall pattern except at Herero, which is characterized by unimodal rainy season.

The SARC is located at $7^{\circ} 7^{\prime} \mathrm{N}$ and $40^{\circ} 10^{\prime} \mathrm{E}$, at 2400 meters above sea level (masl) and $463 \mathrm{~km}$ southeast of Addis Ababa in Bale zone. It receives an average annual rainfall of $808 \mathrm{~mm}$. The monthly averages of minimum and maximum temperatures are 9.3 and $20.9{ }^{\circ} \mathrm{C}$, respectively. The dominant soil type is pellic Vertisols with slightly acidic soil reaction. Agarfa is located at $7^{\circ} 17^{\prime}$ $\mathrm{N}$ and $39^{\circ} 49^{\prime} \mathrm{E}$ and 2530 masl in a cool, sub-humid agro-climatic zone of Bale. Its average annual rainfall is $833 \mathrm{~mm}$. The dominant soil type is pellic Vertisols. Herero is located at 2365 masl with a unimodal rainfall pattern and average annual rainfall of $781 \mathrm{~mm}$.

\subsection{Urediospore Trapping}

Monthly total urediospore counts for Puccinia graminis were determined using Burkard 7-days volumetric spore trap (Burkard Scientific Instrument Rickmanswork, Hertfordshire) during the cropping seasons from 2001 to 2006. The device was mounted on a stand so that the intake orifice was at a height of $1.9 \mathrm{~m}$ from the ground surface. The diameter of the orifice was $2 \mathrm{~mm} \times 14 \mathrm{~mm}$, oriented towards the direction of the wind led by the vane. Air was drawn in through a slot at a rate of 10 liters per minute. The air passed by an adhesive coated tape attached to a drum rotated by a clock. One strip of tape was sufficient for one week of collection. The tape was surface coated with a mixture of $35 \mathrm{~g}$ gelvatol $(1000 \mathrm{ml}$ distilled water, $50 \mathrm{ml}$ glycerol and phenol). Daily trapped spores were determined on the basis of $48 \mathrm{~mm}$ of the exposed tape per day. The daily exposed tape was divided into five sections and mounted on a light microscope slide to inspect the spore with magnification of 400x. The actual area of 15 magnification field was $2.3866 \mathrm{~mm}^{2}$. Representing the number of spores counted on 2.3866 $\mathrm{mm}^{2}$ by " $\mathrm{K}$ ", the total number of daily trapped spores (T) was estimated from the total area, $48 \mathrm{~mm} \times 14 \mathrm{~mm}=672$ $\mathrm{mm}^{2}$ of the adhesive tape exposed to spores by the formula $\mathrm{T}=\left(\mathrm{K} \times 672 \mathrm{~mm}^{2}\right) / 2.3866 \mathrm{~mm}^{2}$.
Given that 10 liters of air was sucked per minute and 1 $\mathrm{m}^{3}$ of air represents 1000 liters, the amount of air sucked per day was determined to be $14.4 \mathrm{~m}^{3}$. With this assumption, the adjusted number of spores (A) per $\mathrm{m}^{3}$ of air was estimated by the formula; $A=K \times 672$ $\left.\mathrm{mm}^{2}\right) / 2.3866 \mathrm{~mm}^{2} \times 14.4 \times 70$.

\subsection{Disease Monitoring Using Trap Plots}

Epidemics of stem rust were monitored using disease trap plots established at the three major wheat growing and rust prone districts of Bale. The nurseries consisted of 15 to 21 durum wheat advanced lines and commercial cultivars with different degrees of resistance to stem rust. Thirty-two stem rust differential lines with known Sr genes were also planted at Sinana to monitor effective genes against stem rust pathotypes. About 22 commercial bread wheat varieties were included for comparisons. The genotypes were planted in non-replicated nursery in two rows of $1 \mathrm{~m}$ long and $0.4 \mathrm{~m}$ wide plots. A seed rate of 150 $\mathrm{kg} \mathrm{ha}{ }^{-1}$ was used. Fertilizer rate of $41-46 \mathrm{~kg} \mathrm{~N}-\mathrm{P}_{2} \mathrm{O}_{5} \mathrm{ha}^{-1}$ was applied at planting. Weeds were removed manually as needed. Stem rust severity and reaction were recorded using the Modified Cobb scale (Peterson et al., 1949). Terminal levels of rust severity were used to measure stem rust variability among the cultivars.

\section{Results}

\subsection{Urediospore Movement}

In each season, traps of urediospores of $P$. graminis at Sinana were more abundant during the months of October-January than during the other months (Figure 1). The exception was in 2002 and 2006 during which urediospores were trapped in large quantities as of November. This peak catch corresponds with crop growth stage when stem rust infection is normally apparent in the field (Table 1). Number of urediospores per $\mathrm{m}^{3}$ of air was generally low during the off-season months. However, it tended to slightly increase during the months of May to mid-June during 2002, 2004 and 2006 cropping seasons, while this increase was extended towards mid July to August during the 2001 cropping season. In 2005, the load of urediospore concentration was extremely low during the months of March to August. Spore concentration started to increase as of September during this season. Peak concentration of urediospores during this year was also comparatively lower, which is about 613.8 urediospores per $\mathrm{m}^{3}$ of air trapped in the month of December (Figure 1). A similar pattern of urediospore movement was observed in 2003 with that of 2005, except that a slight increase in urediospore concentration was observed during 2003 in July. Urediospore was trapped all through the year in the 2002 cropping season. Overall, the highest spore movement was obtained in the 2001 cropping season. The peak number of urediospores count during this season was about 2629.7 per $\mathrm{m}^{3}$ of air. In all years except 2002 , concentration of the pathogen entity trapped during the months of March to May was very low, approaching zero. The highest urediospore concentration was trapped in the month of December during 2002 and 2006 and in November and January during 2003 and 2004, respectively (Figure 1). 
2001

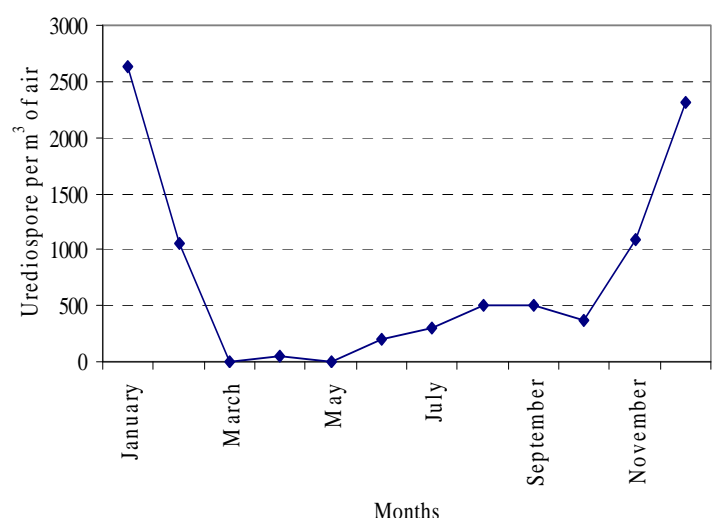

2003

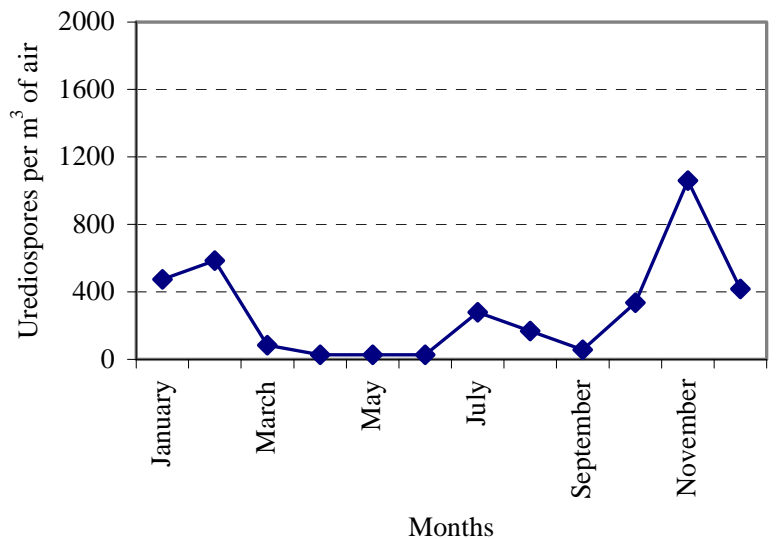

2005

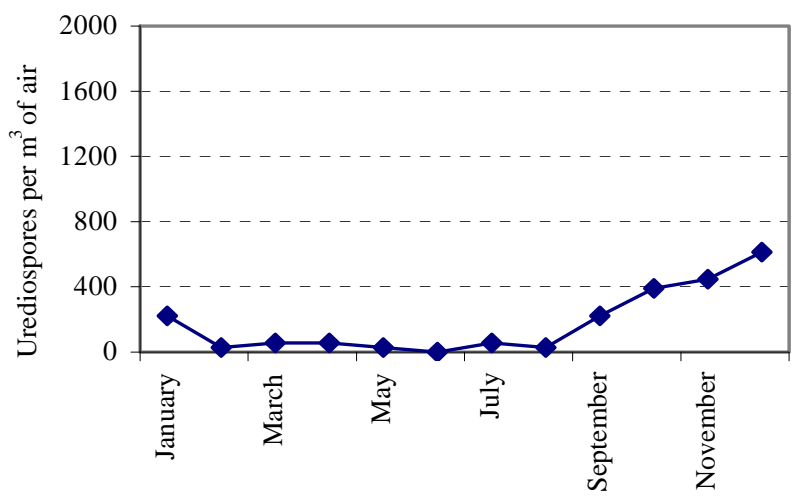

Months
2002

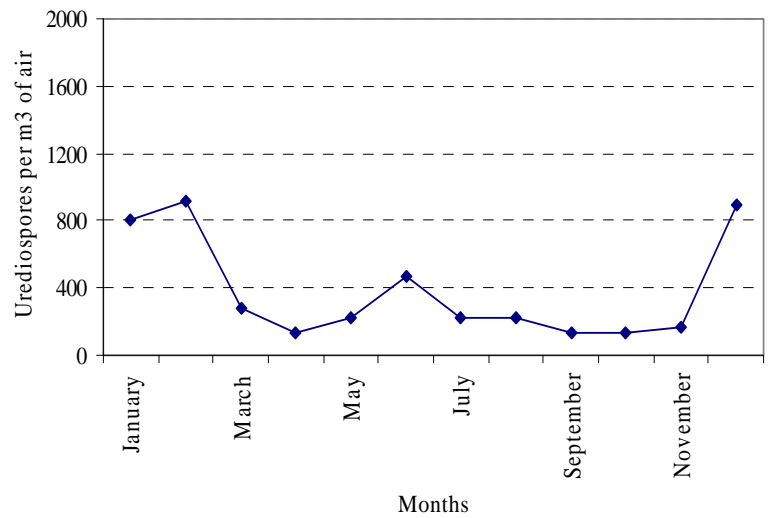

2004

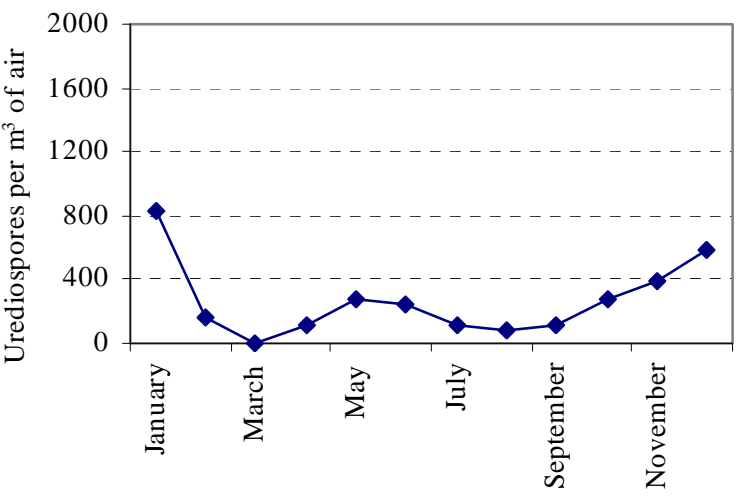

Months

2006

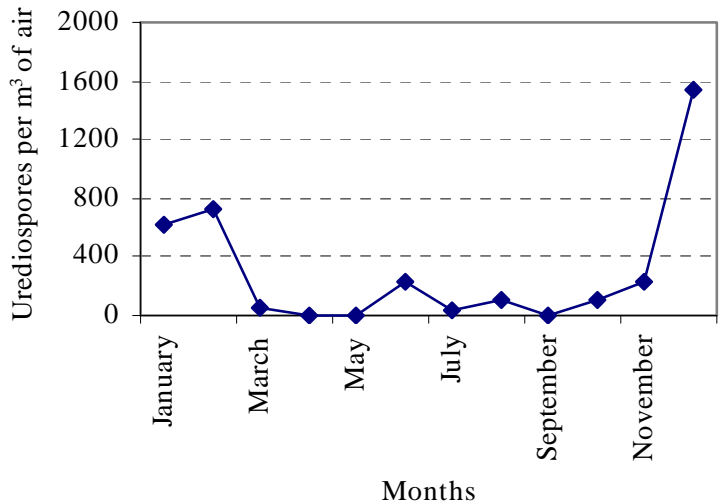

Months

Figure 1. Patterns of seasonal distribution of urediospores of Puccinia graminis at Sinana during 2001-2006 cropping season.

In the 2001 cropping season, the first stem rust symptom was apparent in the field on susceptible cultivars in nursery plots during the last week of September while it appeared very late in 2002, during late November (Table 1). In 2003 and 2004, the first stem rust uredinium was observed during the early week of November. It was observed very early in 2005 and 2006, during the first week of October. 
Table 1. Appearance of the first uredia of stem rust on susceptible wheat cultivars at Sinana during the main cropping seasons of 2001-2006.

\begin{tabular}{llll}
\hline Year & Planting date & Date of first uredia appearance & Crop growth at first uredia appearance \\
\hline 2001 & August 21 & September 23 & Tillering \\
2002 & August 26 & November 27 & Booting \\
2003 & August 18 & November 3 & Early flowering \\
2004 & August 24 & November 8 & Complete flowering \\
2005 & August 29 & October 7 & Heading \\
2006 & August 08 & October 4 & Stem elongation \\
\hline
\end{tabular}

\subsection{Stem Rust Epidemics}

During the 2001 crop season, high levels of stem rust epidemic were recorded at Sinana in which several commercial and newly released durum wheat cultivars became susceptible to the disease. More than $60 \%$ of the tested cultivars exhibited stem rust severity in the range of 30-60\% (Modified Cobb Scale) (Table 2). Four durum commercial wheat cultivars; Cocorit 71, Gerardo, DZ 1928-2 and DZ 2234 had a good level of resistance to stem rust during the 2001 season. Moderate levels of stem rust epidemics were present at Herero during this season (Table 3). Maximum stem rust severity of $25 \%$ was recorded on cultivars Kilinto, Bichena and Quamy, while more than $73 \%$ of the cultivars showed relatively low resistance reaction (less than 15\%) to the existing stem rust pathotypes. At Agarfa, low levels of stem rust severity were recorded during the 2001 crop season (Table 4). Only cultivars Foka, DZ 2085 (Asasa) and Kilinto exhibited relatively high levels of stem rust severity, about 20,20 and $15 \%$, respectively.

As dry conditions prevailed during the entire season of 2002 at Sinana, a moderate level of stem rust epidemics was observed. Cultivar DZ 04-118 exhibited the highest stem rust severity $(40 \%)$ while lower disease severity was recorded on the other cultivars (Table 2). At Herero, weather conditions during 2002 appeared to be conducive for stem rust development as evidenced by the high level of stem rust epidemics recorded. About $50 \%$ of the test cultivars showed stem rust severity in the range of 25$60 \%$ (Table 3). Moderate levels of stem rust epidemics were recorded at Agarfa and Sinana during the 2003 cropping season while a low level of disease epidemic was recorded at Herero during the season. Conversely, low levels of stem rust epiphytotics were observed at Agarfa and Herero and moderate level at Sinana during the 2004 season. Only trace to $5 \%$ stem rust severity was observed at Agarfa and Herero. The highest stem rust severity of $30 \%$ was recorded on the cultivars DZ 04-118 and DZ 2085 at Sinana during 2004 (Table 2). Reasonable level of disease severity was recorded at Herero during 2005 in which thirteen of the twenty durum wheat cultivars tested exhibited stem rust severity of $20 \%$ or higher (Table 3). Stem rust development was low at Agarfa and Sinana during the 2005, while relatively appreciable levels of disease severity were recorded at Sinana and Herero during the 2006 cropping season.

Five durum wheat cultivars, Cocorit 71, Gerardo, DZ 1928-2, DZ-2234 and CD 95759-11M were consistently resistant to stem rust at all locations and over years (Tables 2, 3 and 4). Other cultivars such as DZ 04-118, Boohai, Foka, Kilinto, Bichena, Quamy, Asasa, DZ 1050 and CD 96643-64 were generally susceptible at all locations. Robe and CD-95324 showed differential response over locations perhaps indicating variability in pathogenecity.

\subsection{Virulence Status and Effective Genes}

Based on their field reaction, virulence for several of the Sr genes (stem rust differential lines) tested was detected at Sinana. However, Sr 6, Sr 18, Sr 22 and Sr $26+$ Sr 9g provided relatively better protection to the prevailing stem rust population under field conditions (Table 5). The stem rust resistant gene $\mathrm{Sr} 31$, which has been extensively employed in most wheat germplasms widely cultivated in different parts of the world was found to be ineffective showing severe level stem rust infection. 
Table 2. Levels of stem rust severitya on durum wheat cultivars at Sinana during the main seasons of 2001-2006.

\begin{tabular}{|c|c|c|c|c|c|c|}
\hline Durum wheat cultivars & 2001 & 2002 & 2003 & 2004 & 2005 & 2006 \\
\hline DZ $04-118$ & $30 \mathrm{~s}$ & $40 \mathrm{~s}$ & $40 \mathrm{~s}$ & $30 \mathrm{~s}$ & $20 \mathrm{~s}$ & $20 \mathrm{~ms}$ \\
\hline Cocorit 71 & $5 \mathrm{~ms}$ & Trs & $20 \mathrm{~ms}$ & $5 \mathrm{~ms}$ & Tms & 0 \\
\hline Gerardo & $5 \mathrm{~s}$ & Trs & $10 \mathrm{~s}$ & tms & Tms & 0 \\
\hline LD 357 & $25 \mathrm{mr}$ & $5 \mathrm{~s}$ & $25 \mathrm{~s}$ & $5 s$ & Tms & $15 \mathrm{~s}$ \\
\hline Boohai & $40 \mathrm{~s}$ & $20 \mathrm{~s}$ & $15 \mathrm{~s}$ & tms & $10 \mathrm{~s}$ & $30 \mathrm{~s}$ \\
\hline Foka & $30 \mathrm{~s}$ & $20 \mathrm{~s}$ & $20 \mathrm{~s}$ & $15 \mathrm{~s}$ & $10 \mathrm{~s}$ & $25 \mathrm{~s}$ \\
\hline Kilinto & $40 \mathrm{~s}$ & $10 \mathrm{~s}$ & $25 \mathrm{~s}$ & $5 s$ & $20 \mathrm{~s}$ & $30 \mathrm{~s}$ \\
\hline Bichena & $40 \mathrm{~s}$ & $15 \mathrm{~s}$ & $10 \mathrm{~ms}$ & $15 \mathrm{~s}$ & Tmr & $25 \mathrm{~s}$ \\
\hline Quamy & $40 \mathrm{~s}$ & $10 \mathrm{~s}$ & $25 \mathrm{~s}$ & $15 \mathrm{~ms}$ & $20 \mathrm{~ms}$ & $30 \mathrm{~s}$ \\
\hline TOB 66 & $25 \mathrm{~ms}$ & Trs & $20 \mathrm{~s}$ & $5 \mathrm{~ms}$ & $15 \mathrm{~ms}$ & $20 \mathrm{~s}$ \\
\hline DZ 2085 (Asasa) & $60 \mathrm{~s}$ & $25 \mathrm{~s}$ & $40 \mathrm{~s}$ & $30 \mathrm{~s}$ & $10 \mathrm{~ms}$ & $\operatorname{trs}$ \\
\hline DZ 1928-2 & tms & Trs & $25 \mathrm{~s}$ & $15 \mathrm{~s}$ & $10 \mathrm{~ms}$ & - \\
\hline DZ 1640 (Robe) & $40 \mathrm{~s}$ & $10 \mathrm{~s}$ & $15 \mathrm{~ms}$ & $5 \mathrm{~s}$ & $5 \mathrm{~ms}$ & $10 \mathrm{~ms}$ \\
\hline DZ 1050 (Ginchi) & $40 \mathrm{~s}$ & $20 \mathrm{~s}$ & $20 \mathrm{~s}$ & $10 \mathrm{~s}$ & $15 \mathrm{~ms}$ & $10 \mathrm{~s}$ \\
\hline DZ 1052 & $40 \mathrm{~s}$ & $10 \mathrm{~s}$ & $15 \mathrm{~ms}$ & $10 \mathrm{~s}$ & NT & NT \\
\hline DZ-2234 & 0 & $5 \mathrm{~s}$ & $\operatorname{tmr}$ & 0 & NT & NT \\
\hline CD-95324 & $40 \mathrm{~ms}$ & $5 \mathrm{~s}$ & $10 \mathrm{~ms}$ & $5 \mathrm{~s}$ & NT & NT \\
\hline CD-95759-11M & $15 \mathrm{mr}$ & Trs & $5 \mathrm{~ms}$ & 0 & NT & NT \\
\hline CD-95924-IV & $20 \mathrm{~ms}$ & $5 \mathrm{~s}$ & $5 \mathrm{~s}$ & $5 s$ & NT & NT \\
\hline CD-96643-6Y & $30 \mathrm{~ms}$ & $5 s$ & $25 \mathrm{~s}$ & $15 \mathrm{~s}$ & NT & NT \\
\hline Ude & $\mathrm{NT}^{\mathrm{a}}$ & NT & $15 \mathrm{~ms}$ & $\operatorname{trs}$ & 0 & $10 \mathrm{~s}$ \\
\hline Yerer & NT & NT & $10 \mathrm{~s}$ & 0 & 0 & $20 \mathrm{~s}$ \\
\hline DZ-1838-3dzr-/dz05 & NT & NT & $5 \mathrm{~ms}$ & $5 \mathrm{~s}$ & $\mathrm{tms}$ & 0 \\
\hline
\end{tabular}

a Terminal stem rust severity was assessed using the Modified Cobb's scale (Peterson et al., 1949)

Table 3. Levels of stem rust severity a on different durum wheat cultivars at Herero in the main seasons of 2001-2006.

\begin{tabular}{|c|c|c|c|c|c|c|}
\hline Durum wheat cultivars & 2001 & 2002 & 2003 & 2004 & 2005 & 2006 \\
\hline DZ $04-118$ & $10 \mathrm{~ms}$ & $25 \mathrm{~s}$ & $10 \mathrm{~s}$ & 0 & $50 \mathrm{~s}$ & $40 \mathrm{~s}$ \\
\hline Cocorit 71 & $5 \mathrm{~ms}$ & $10 \mathrm{~ms}$ & $10 \mathrm{~s}$ & 0 & $25 \mathrm{~s}$ & $25 \mathrm{~s}$ \\
\hline Gerardo & 0 & $5 s$ & $5 s$ & 0 & $15 \mathrm{~ms}$ & $5 \mathrm{~s}$ \\
\hline LD 357 & 0 & $15 \mathrm{~ms}$ & $10 \mathrm{~s}$ & 0 & $30 \mathrm{~s}$ & $20 \mathrm{~s}$ \\
\hline Boohai & $10 \mathrm{~s}$ & $40 \mathrm{~s}$ & $\operatorname{trs}$ & 0 & $20 \mathrm{~ms}$ & $10 \mathrm{~s}$ \\
\hline Foka & $15 \mathrm{~s}$ & $40 \mathrm{~s}$ & $10 \mathrm{~s}$ & 0 & $25 \mathrm{~ms}$ & $30 \mathrm{~s}$ \\
\hline Kilinto & $25 \mathrm{~s}$ & $30 \mathrm{~s}$ & $5 s$ & 0 & $20 \mathrm{~s}$ & $30 \mathrm{~s}$ \\
\hline Bichena & $25 \mathrm{~s}$ & $30 \mathrm{~s}$ & trs & 0 & $\mathrm{tmr}$ & $20 \mathrm{~s}$ \\
\hline Quamy & $25 s$ & $30 \mathrm{~s}$ & $\operatorname{trs}$ & 0 & $15 \mathrm{~ms}$ & $15 \mathrm{~s}$ \\
\hline TOB 66 & $5 \mathrm{~ms}$ & $20 \mathrm{~s}$ & $\operatorname{trs}$ & 0 & $\mathrm{tmr}$ & $10 \mathrm{~s}$ \\
\hline DZ 2085 (Asasa) & $5 \mathrm{~ms}$ & $25 \mathrm{~s}$ & $5 \mathrm{~s}$ & $\operatorname{trs}$ & $30 \mathrm{~ms}$ & $15 \mathrm{~s}$ \\
\hline DZ 1928-2 & 0 & $5 s$ & $5 \mathrm{~s}$ & 0 & $15 \mathrm{~ms}$ & - \\
\hline DZ 1640 (Robe) & $15 \mathrm{~s}$ & $60 \mathrm{~s}$ & $10 \mathrm{~s}$ & 0 & $30 \mathrm{~ms}$ & $10 \mathrm{~s}$ \\
\hline DZ 1050 (Ginchi) & $10 \mathrm{~s}$ & $60 \mathrm{~s}$ & $\operatorname{trs}$ & - & $30 \mathrm{~ms}$ & $10 \mathrm{~s}$ \\
\hline DZ 1052 & $20 \mathrm{~s}$ & $60 \mathrm{~s}$ & $5 \mathrm{~s}$ & 0 & $30 \mathrm{~ms}$ & NT \\
\hline DZ-2234 & NT & 0 & $15 \mathrm{~s}$ & 0 & $10 \mathrm{~ms}$ & NT \\
\hline CD-95324 & NT & $10 \mathrm{~ms}$ & $5 s$ & 0 & $20 \mathrm{~ms}$ & NT \\
\hline CD-95759-11M & NT & $15 \mathrm{~ms}$ & trs & 0 & $15 \mathrm{~ms}$ & NT \\
\hline CD-95924-IV & NT & $40 \mathrm{mr}$ & $5 \mathrm{~s}$ & 0 & $60 \mathrm{~s}$ & NT \\
\hline CD-96643-6Y & NT & $40 \mathrm{mr}$ & $20 \mathrm{~s}$ & 0 & $30 \mathrm{~s}$ & NT \\
\hline
\end{tabular}

${ }^{a}$ Terminal stem rust severity was assessed using the Modified Cobb's scale (Peterson et al., 1949) 
Table 4. Levels of stem rust severity a on different durum wheat cultivars at Agarfa in the main cropping seasons of 20012006.

\begin{tabular}{|c|c|c|c|c|c|}
\hline Durum wheat cultivars & 2001 & 2003 & 2004 & 2005 & 2006 \\
\hline Cocorit 71 & trs & $5 \mathrm{~ms}$ & trs & tms & - \\
\hline Gerardo & 0 & $\mathrm{tms}$ & 0 & 0 & 0 \\
\hline LD 357 & $10 \mathrm{~ms}$ & $30 \mathrm{~ms}$ & 0 & $5 \mathrm{~ms}$ & 0 \\
\hline Boohai & 0 & $15 \mathrm{~ms}$ & $5 \mathrm{~s}$ & 0 & $5 \mathrm{mr}$ \\
\hline Foka & $20 \mathrm{~s}$ & $20 \mathrm{~s}$ & 0 & $10 \mathrm{~s}$ & $10 \mathrm{~ms}$ \\
\hline Kilinto & $15 \mathrm{~s}$ & $10 \mathrm{~ms}$ & 0 & 0 & $10 \mathrm{~s}$ \\
\hline Bichena & 0 & $5 s$ & 0 & 0 & $10 \mathrm{~s}$ \\
\hline Quamy & $5 \mathrm{~ms}$ & $10 \mathrm{~ms}$ & 0 & $\mathrm{tms}$ & $5 \mathrm{~s}$ \\
\hline TOB 66 & 0 & $5 \mathrm{~ms}$ & 0 & 0 & $5 \mathrm{~s}$ \\
\hline DZ 2085 (Asasa) & $20 \mathrm{~ms}$ & $60 \mathrm{~s}$ & 0 & $15 \mathrm{~ms}$ & 0 \\
\hline DZ 1928-2 & $10 \mathrm{~ms}$ & $15 \mathrm{~ms}$ & 0 & $5 \mathrm{~ms}$ & 0 \\
\hline DZ 1640 (Robe) & 0 & $5 \mathrm{~ms}$ & 0 & $5 \mathrm{~ms}$ & $\operatorname{trs}$ \\
\hline DZ 1050 (Ginchi) & 0 & $5 \mathrm{~ms}$ & 0 & $5 \mathrm{~ms}$ & 0 \\
\hline DZ 1052 & $10 \mathrm{~ms}$ & $5 \mathrm{~ms}$ & 0 & tms & NT \\
\hline DZ-2234 & NT & $\mathrm{tms}$ & 0 & - & NT \\
\hline CD-95324 & NT & $5 \mathrm{~ms}$ & - & tms & NT \\
\hline CD-95759-11M & NT & tms & $\operatorname{trs}$ & tms & NT \\
\hline CD-95924-IV & NT & $5 \mathrm{~ms}$ & 0 & tms & NT \\
\hline CD-96643-6Y & NT & $5 \mathrm{~ms}$ & 0 & - & NT \\
\hline
\end{tabular}

\section{Discussion}

The study indicated that stem rust urediospores exist in the air almost throughout the entire year, although the concentration varied depending on the time of cropping season and weather conditions. During the months of crop free period, the number of urediospores per $\mathrm{m}^{3}$ of air was generally low but was rarely reduced to zero. This is in agreement with previous findings by Saari and Prescott (1985) and Mamuluk (2000) who have reported the existence of local inoculum and endemic disease cycle all year round in the major epidemiological zones of the Africa south of the Sahara and southwestern Arabian Peninsula which includes Ethiopia, Kenya, Yemen, Tanzania and many other African countries. It has also been reported that the Ethiopian highlands are particularly unique from other countries in the zone as these are centers of diversity for rust fungal populations providing much of the inoculum for cereals grown in other countries (Saari and Prescott, 1985).

Appreciable quantities of urediospores were evident much earlier before the first stem rust uredia apparently observed during the season. This substantiates the probability that the majority of spores caught originated locally. Urediospores from volunteer or self-sown plants may, therefore, remain the principal source of primary inoculum for annual infection of wheat by stem rust in southeastern areas of Ethiopia. The bimodal rainfall pattern and wheat-based monocropping practice in the Bale highlands provides a green bridge between two seasons and allows availability of volunteer wheat plants. This makes the pathogen generate successful successive uredial stage and also enables it to effectively over season within the main wheat growing areas of southeastern Ethiopia (Roelfs, 1985; Bekele, 2003). Such foci provide initial inoculum which can dependably provoke stem rust epidemics each year in Bale. Roelfs (1985) and Saari and Prescott (1985) also reported that the stem rust fungus mainly persists on volunteer cereal plants or on successive crops as they are planted at different times of the year depending mainly on altitude and rainfall pattern in the area and the role of berberies and grasses as reservoirs of inoculum for the main crop, where wheat is not important.

Urediospore concentration tended to increase slightly during the second (ganna) season, which indicates that this season can provide a viable source of primary inoculum for infection during the main (bona) season, although the second season is not generally conducive for the development of cereal rust epidemics in Bale (Bekele, 2003). Hence, it can be concluded that the occurrence and distribution of stem rust epidemics in the Bale highlands are largely determined by suitable weather conditions and availability of susceptible hosts.

The importance of long distance transported spores also cannot be ruled out as similarities exist in race patterns between Ethiopia and some other African countries such as Kenya, Uganda and Tanzania which represent the common sub-epidemiological zone for cereal rusts in East Africa (Saari and Prescott, 1985). Mamuluk et al. (2000) reported the existence of optimum conditions for crop growth and spore movement among some African countries such as Ethiopia, Sudan, Kenya and Tanzania. In Ethiopia, Johnson et al. (1967) reported that there is no evidence for the transport of spores from outside the country. Guthrie (1966) also reported evidence that the rapid turnover of wheat stem rust races in Kenya is related to the dispersal of spores from Ethiopia due to the northeast monsoon wind, which 
blows from November to March carrying stem rust spores from the wheat growing areas of Ethiopia to those of Kenya. Therefore, Ethiopia as an ancient region of wheat cultivation may contain an extensive pool of rust genes for virulence which could be regarded as the major sources of inoculum of wheat stem rust pathogen in eastern Africa. Long-distance transported urediospores have actually little effect on the subsequent development of the epidemic (Peterson, 2001). Rees (1971) also reported that stem rust epidemics developed from spores transported over longer distances is of minor importance while small sources of inoculum from close proximity to the young crop are normally of greater importance in the development of a particular epidemic. Primary infection from long-distance transported urediospores occurs much later than when primary infections occur from urediospores locally produced from over-wintered mycelium and subsequent development of uredinia and will have the advantage of several more generations of spore-to-spore development before the host plants mature (Eversmeyer and Kramer, 2000). However, longdistance transported spore appears to be of particular importance in the distribution of genetic novelty in the rust organisms over vast areas (Rees, 1971).

Table 5. Performance of stem rust resistance (Sr) genes at Sinana during the main cropping seasons of 2001-2004.

\begin{tabular}{|c|c|c|c|c|c|}
\hline \multirow[b]{2}{*}{ Differential line } & \multirow[b]{2}{*}{ Sr gene } & \multicolumn{4}{|c|}{ Stem rust severity } \\
\hline & & 2001 & 2002 & 2003 & 2004 \\
\hline ISR5-Ra & Sr $5 \mathrm{a}$ & $40 \mathrm{~s}$ & - & - & - \\
\hline PDSr6KY58 & Sr 6 & $25 \mathrm{~s}$ & $20 \mathrm{~s}$ & - & 0 \\
\hline MEDINOS/W2691/?/W3498 & Sr $7 a+10$ & $40 \mathrm{~s}$ & $60 \mathrm{~s}$ & $60 \mathrm{~s}$ & $30 \mathrm{~s}$ \\
\hline ISR7B-Ra & Sr $7 b$ & $60 \mathrm{~s}$ & $40 \mathrm{~s}$ & $60 \mathrm{~s}$ & $40 \mathrm{~s}$ \\
\hline BARNETA BENBENUTO & Sr $8 b$ & $20 \mathrm{~s}$ & $20 \mathrm{~s}$ & $40 \mathrm{~s}$ & $60 \mathrm{~s}$ \\
\hline W2691Sr9D & Sr 9d & $60 \mathrm{~s}$ & $60 \mathrm{~s}$ & $60 \mathrm{~s}$ & - \\
\hline VERNESTEIN & Sr $9 \mathrm{e}$ & $40 \mathrm{~s}$ & $40 \mathrm{~s}$ & $60 \mathrm{~s}$ & $40 \mathrm{~s}$ \\
\hline Sr9g(J2N)N.N.SEL & Sr $9 \mathrm{~g}$ & $40 \mathrm{~s}$ & $60 \mathrm{~s}$ & $60 \mathrm{~s}$ & $60 \mathrm{~s}$ \\
\hline W2691Sr10 & Sr 10 & $60 \mathrm{~s}$ & $60 \mathrm{~s}$ & $60 \mathrm{~s}$ & $60 \mathrm{~s}$ \\
\hline ISr11-Ra & Sr 11 & $40 \mathrm{~s}$ & $60 \mathrm{~s}$ & $60 \mathrm{~s}$ & $60 \mathrm{~s}$ \\
\hline BtSr12TC & Sr 12 & $40 \mathrm{~s}$ & $30 \mathrm{~s}$ & $40 \mathrm{~s}$ & $60 \mathrm{~s}$ \\
\hline W2691Sr13 & Sr 13 & $30 \mathrm{~s}$ & $25 \mathrm{~s}$ & $40 \mathrm{~s}$ & $50 \mathrm{~s}$ \\
\hline LINE A SELECTION & Sr 14 & $40 \mathrm{~s}$ & $40 \mathrm{~s}$ & $60 \mathrm{~s}$ & $40 \mathrm{~s}$ \\
\hline W2691SR15NK & Sr 15 & $60 \mathrm{~s}$ & $40 \mathrm{~s}$ & $60 \mathrm{~s}$ & $40 \mathrm{~s}$ \\
\hline CONBINATION VII & Sr $17+$ Sr 13 & $80 \mathrm{~s}$ & $25 \mathrm{~s}$ & $25 \mathrm{~s}$ & $60 \mathrm{~s}$ \\
\hline LCSr 18RL & Sr 18 & $5 \mathrm{~ms}$ & 0 & $20 \mathrm{~s}$ & $25 \mathrm{~s}$ \\
\hline LCSR 19MG & Sr 19 & $60 \mathrm{~s}$ & $40 \mathrm{~s}$ & $60 \mathrm{~s}$ & $15 \mathrm{~s}$ \\
\hline T.MONOCOCUM DERIV & Sr 21 & $30 \mathrm{~s}$ & $25 s$ & $30 \mathrm{~s}$ & $40 \mathrm{~s}$ \\
\hline SWSR 22Tb & Sr 22 & $10 \mathrm{~ms}$ & $30 \mathrm{~s}$ & $20 \mathrm{~s}$ & - \\
\hline LCSr25 Ars & Sr 25 & $80 \mathrm{~s}$ & $20 \mathrm{~s}$ & $40 \mathrm{~s}$ & $20 \mathrm{~s}$ \\
\hline EAGLE & Sr $26+\operatorname{Sr} 9 \mathrm{~g}$ & $25 \mathrm{~ms}$ & $\operatorname{trs}$ & $10 \mathrm{~s}$ & $20 \mathrm{~s}$ \\
\hline WRT238-5 & Sr 27 & $60 \mathrm{~s}$ & $40 \mathrm{~s}$ & $60 \mathrm{~s}$ & $25 s$ \\
\hline W2691Sr28KT & Sr 28 & $80 \mathrm{~s}$ & $60 \mathrm{~s}$ & $60 \mathrm{~s}$ & $60 \mathrm{~s}$ \\
\hline PUSA *4/ETOIL DE CHOISY & Sr 29 & $60 \mathrm{~s}$ & $40 \mathrm{~s}$ & $40 \mathrm{~s}$ & $40 \mathrm{~s}$ \\
\hline BtSr30Wst & Sr 30 & $40 \mathrm{~s}$ & $25 s$ & $60 \mathrm{~s}$ & $40 \mathrm{~s}$ \\
\hline LINE E/KBZ & Sr 31 & $60 \mathrm{~s}$ & $20 \mathrm{~s}$ & $60 \mathrm{~s}$ & $30 \mathrm{~s}$ \\
\hline ER5155 & Sr 32 & $5 s$ & $25 \mathrm{~S}$ & $60 \mathrm{~s}$ & $30 \mathrm{~s}$ \\
\hline TETRACANTHATCH/AE-SQ[AL5045] & Sr $33+$ Sr 5 & $30 \mathrm{~s}$ & $40 \mathrm{~s}$ & $60 \mathrm{~s}$ & $40 \mathrm{~s}$ \\
\hline W2691SrTt-1 & Sr 36 & $60 \mathrm{~s}$ & $30 \mathrm{~s}$ & $80 \mathrm{~s}$ & $60 \mathrm{~s}$ \\
\hline W2691SrTt-2 & Sr 37 & $15 \mathrm{~s}$ & $50 \mathrm{~s}$ & $60 \mathrm{~s}$ & $60 \mathrm{~s}$ \\
\hline FED*2/SrTt-3 & SrTt3+ Sr 10 & $40 \mathrm{~s}$ & $30 \mathrm{~s}$ & $40 \mathrm{~s}$ & $30 \mathrm{~s}$ \\
\hline
\end{tabular}

Large quantities of urediospores of the pathogen were generally trapped during the months of October/ November - January. This period normally corresponds with the main cropping season and crop growth when stem rust infection is normally apparent in the field. In Bale, main season planting takes place from mid to late August and crop growth may extend to December. Infection of new wheat crops by stem rust commonly 
Kebede and Bekele

occurs starting from the first week of October or may extend up to late November depending on the prevailing weather conditions. Multiple uredial cycle can occur till the crop attains its physiological maturity (until late December), which can result in generations of large quantities of inoculum during the growing season. Low concentrations of urediospores per $\mathrm{m}^{3}$ were trapped during the crop free months. The exception was during the months of May to mid June during which concentration tended to rise as planting of wheat also occurs during the second season (March to July). This season is not actually conducive for rust development, but low levels of infection may occur which contributes to the increase in urediospores concentration during this period.

Variable levels of stem rust epidemics were recorded on durum wheat varieties planted at each location depending on the weather condition, inoculum and the genetic background of the cultivar. In general, only low to moderate levels of stem rust epidemics were recorded on the durum wheat cultivars included in the trap. The only exceptions were at Sinana in 2001 and at Herero in the 2002 cropping seasons during which relatively severe epidemics of stem rust were observed. Some of the cultivars showed dependable resistance to the existing pathogen population, even during the seasons of heavy epidemic. The Arsi-Bale highlands have actually been described as a hot spot for the Triticum-Puccinia system (Mulugeta, 1986). Heavy epidemics of stem rust have
East African Journal of Sciences Volume 3 (2) 178-188

been recorded in this region each year, particularly on bread wheat (Bekele et al., 2002; Bekele, 2003).

The levels of stem rust severity on susceptible bread wheat varieties (Table 6) and stem rust resistance genes described in this study and the concentrations of urediospores trapped are cases in point for the occurrence of severe stem rust epidemics in Bale. The commercial bread wheat cultivars most widely cultivated in Ethiopia such as HAR604, HAR1685, HAR727, HAR1407, included for comparisons (Table 6), exhibited severe levels of stem rust (up to $80 \%$ ) and thus confirmed the occurrence of high disease pressure in the area. The high levels of stem rust severity recorded on most of the differential lines, on the other hand, indicated that most of the known $\mathrm{Sr}$ genes are not effective in the area which could be due to the most frequent changes in virulence of the stem rust population in the Bale highlands. Only a few Sr genes (Sr 6, Sr 18, Sr 22 and Sr 26+Sr 9g) provided relatively better protection to the prevailing stem rust population. Van Ginkil et al. (1989) reported that stem rust races prevalent in Ethiopia are among the most virulent races in the world with wide virulence spectrum and frequent changes in pathogencity. Sr 31 gene, that has been extensively deployed in most wheat germplasms widely cultivated in different parts of the world, was found to be ineffective, bearing witness to the speculation that race $\mathrm{Ug} 99$ is widely distributed in eastern Africa (CIMMYT, 2005).

Table 6. Levels of stem rust severity a on some commercial bread wheat cultivars at Agarfa during the main seasons of 2000-2004.

\begin{tabular}{|c|c|c|c|c|c|c|}
\hline Cultivars & Year of release & 2000 & 2001 & 2002 & 2003 & 2004 \\
\hline HAR1685 & 1995 & $40 \mathrm{~s}$ & $80 \mathrm{~s}$ & $80 \mathrm{~s}$ & $80 \mathrm{~s}$ & $60 \mathrm{~s}$ \\
\hline HAR710 & 1994 & $15 \mathrm{~ms}$ & $30 \mathrm{~s}$ & $40 \mathrm{~s}$ & $80 \mathrm{~s}$ & $30 \mathrm{~s}$ \\
\hline HAR1709 & 1994 & $\operatorname{trs}$ & $15 \mathrm{~ms}$ & $10 \mathrm{~s}$ & $30 \mathrm{~s}$ & $30 \mathrm{~s}$ \\
\hline HAR604 & 1995 & $5 \mathrm{~ms}$ & $25 \mathrm{~s}$ & $40 \mathrm{~s}$ & $60 \mathrm{~s}$ & $40 \mathrm{~s}$ \\
\hline HAR1407 & 1997 & $5 \mathrm{~ms}$ & $40 \mathrm{~s}$ & $30 \mathrm{~s}$ & $80 \mathrm{~s}$ & $70 \mathrm{~s}$ \\
\hline HAR1595 & 1997 & $10 \mathrm{~ms}$ & $80 \mathrm{~s}$ & $40 \mathrm{~s}$ & $80 s$ & $60 \mathrm{~s}$ \\
\hline HAR1522 & 1997 & 0 & $60 \mathrm{~s}$ & $40 \mathrm{~s}$ & $60 \mathrm{~s}$ & $50 \mathrm{~s}$ \\
\hline HAR416 & 1987 & 0 & $5 s$ & $50 \mathrm{~s}$ & $40 s$ & $10 \mathrm{~s}$ \\
\hline HAR719 & - & trms & $60 \mathrm{~s}$ & $30 \mathrm{~s}$ & $60 \mathrm{~s}$ & $60 \mathrm{~s}$ \\
\hline HAR727 & - & trms & $40 \mathrm{~s}$ & $40 \mathrm{~s}$ & $60 s$ & $80 \mathrm{~s}$ \\
\hline HAR720 & - & $5 \mathrm{~ms}$ & $30 \mathrm{~s}$ & $40 \mathrm{~s}$ & $60 \mathrm{~s}$ & $20 \mathrm{~s}$ \\
\hline HAR627 & - & $5 \mathrm{~ms}$ & $30 \mathrm{~s}$ & $50 \mathrm{~s}$ & $60 \mathrm{~s}$ & $30 \mathrm{~s}$ \\
\hline HAR729 & - & 0 & 0 & 0 & $\operatorname{trs}$ & 0 \\
\hline HAR1899 & 1999 & $20 \mathrm{~s}$ & $60 \mathrm{~s}$ & $30 \mathrm{~s}$ & $80 s$ & $40 \mathrm{~s}$ \\
\hline Batu & 1984 & $\mathrm{tmr}$ & $25 \mathrm{~s}$ & $10 \mathrm{~s}$ & $30 \mathrm{~s}$ & - \\
\hline Gara & 1984 & $5 \mathrm{~ms}$ & $25 \mathrm{~s}$ & $40 \mathrm{~s}$ & $80 \mathrm{~s}$ & - \\
\hline Dereselign & 1974 & trms & $10 \mathrm{~s}$ & $10 \mathrm{~s}$ & $30 s$ & $5 s$ \\
\hline Enkoy & - & 0 & 0 & $5 \mathrm{~s}$ & $10 \mathrm{~s}$ & 0 \\
\hline Pavon-76 & 1982 & $10 \mathrm{~s}$ & $40 \mathrm{~s}$ & $30 \mathrm{~s}$ & $80 \mathrm{~s}$ & $60 \mathrm{~s}$ \\
\hline Lakech & 1970 & $25 \mathrm{~s}$ & $60 \mathrm{~s}$ & $25 \mathrm{~s}$ & $60 \mathrm{~s}$ & $30 \mathrm{~s}$ \\
\hline Dashen & 1984 & $5 \mathrm{~ms}$ & $20 \mathrm{~ms}$ & $20 \mathrm{~s}$ & $40 s$ & $15 \mathrm{~s}$ \\
\hline ET-13 & 1981 & trms & $60 \mathrm{~s}$ & $30 \mathrm{~s}$ & $80 \mathrm{~s}$ & $60 \mathrm{~s}$ \\
\hline
\end{tabular}

a Terminal stem rust severity was assessed using the Modified Cobb's scale (Peterson et al., 1949)

Environmental conditions in Bale are in the range of conducive weather requirements for stem rust development (Table 7 and Figures 3). From the 17 years weather data, it is evident that the average maximum (21.7 
$\left.{ }^{\circ} \mathrm{C}\right)$ and minimum $\left(8.3^{\circ} \mathrm{C}\right)$ temperatures during the main seasons are within the optimum range (average of 19.5 ${ }^{0} \mathrm{C}$ ) for stem rust development (Roelfs et al., 1992). In Bale, maximum temperature tends to increase from early November to December (Table 7), which creates a conducive environment for sporulation of the pathogen. Average relative humidity also tended to rise during the months of mid October to early November (Figure 2) while the peak rainfall occurs in September followed by October (Figure 3), generally indicating suitability for infection of stem rust pathogen during these periods. In 2002 at Sinana, low to moderate levels of stem rust severity and also low concentration of urediospores per $\mathrm{m}^{3}$ of air were recorded.

The performance of durum wheat cultivars under such epidemic occurrence of the disease provides evidence for the existence of satisfactory durable resistance within the tetraploid wheat species. Ethiopia is known to be the center of diversity of tetraploid wheat species, which presents high genetic diversity for disease resistance and other merits (Ephrem et al., 2000; Naod et al., 2007). Sewalem et al. (2000) also reported the existence of stability of stem rust resistance in some durum wheat cultivars in Ethiopia. Such potentials need to be considered in the development of cultivars with broad genetic basis.

In conclusion, the present study showed that the occurrence and distribution of wheat stem rust are largely determined by suitable weather conditions and availability of susceptible hosts as inoculum of local origin in sufficient quantity exists all year round. Weather conditions in the Bale highlands are mostly within the range of optimum requirements for the epidemic occurrence of the disease when susceptible cultivars are used. On the other hand, wheat stem rust management strategy in Ethiopia should focus on the development of resistant cultivars with a wide genetic base. Breeders should consider the sources of resistance existing within the tetraploid wheat species, particularly durum wheat, and incorporation of effective genes in the development of resistant cultivars with a wider genetic basis.

Table 7. Monthly average (1990-2006) minimum and maximum temperatures (August to December) at the Sinana Agricultural Research Center.

\begin{tabular}{lcc}
\hline & \multicolumn{2}{c}{ Monthly temperature $\left({ }^{0} \mathrm{C}\right)$} \\
\cline { 2 - 3 } Month & Minimum & Maximum \\
\hline August & 9.7 & 20.8 \\
September & 9.9 & 20.1 \\
October & 8.7 & 19.4 \\
November & 8.2 & 20.1 \\
December & 8.3 & 21.7 \\
Mean & 9.0 & 20.4 \\
\hline
\end{tabular}

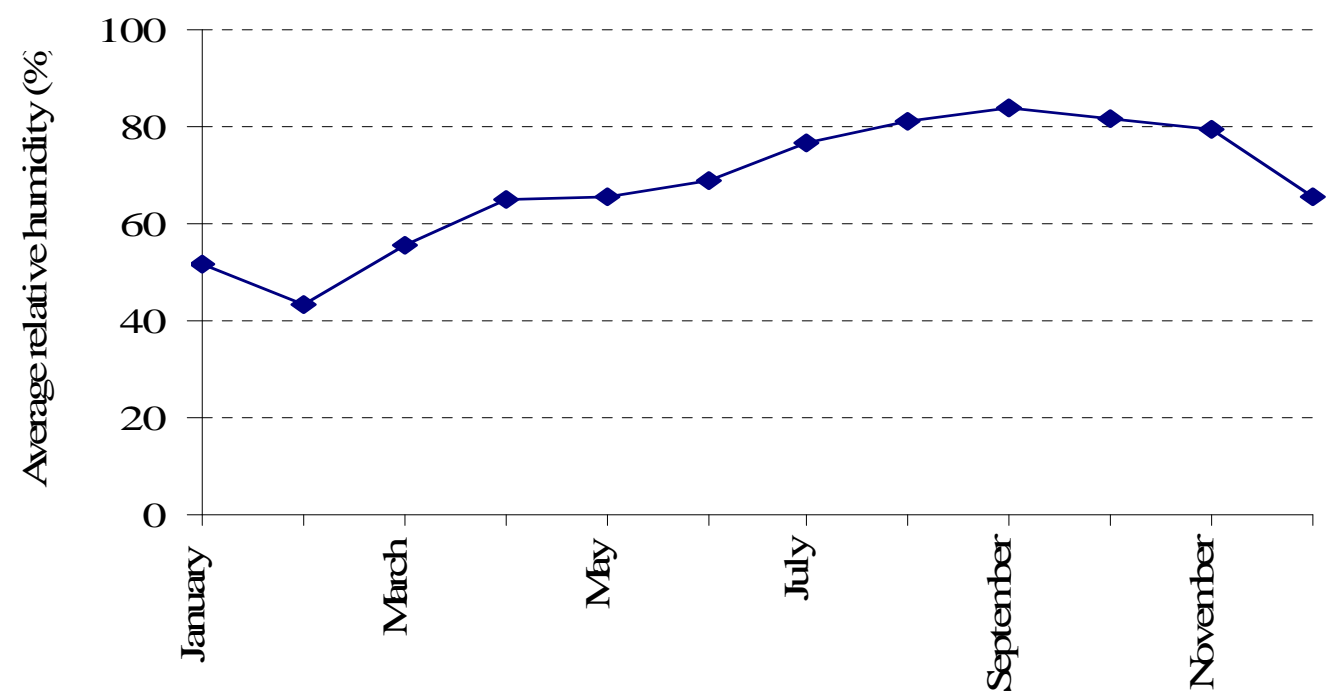

Months

Figure 2. Average (2001-2005) relative humidity (\%) at the Sinana Agricultural Research Center. 


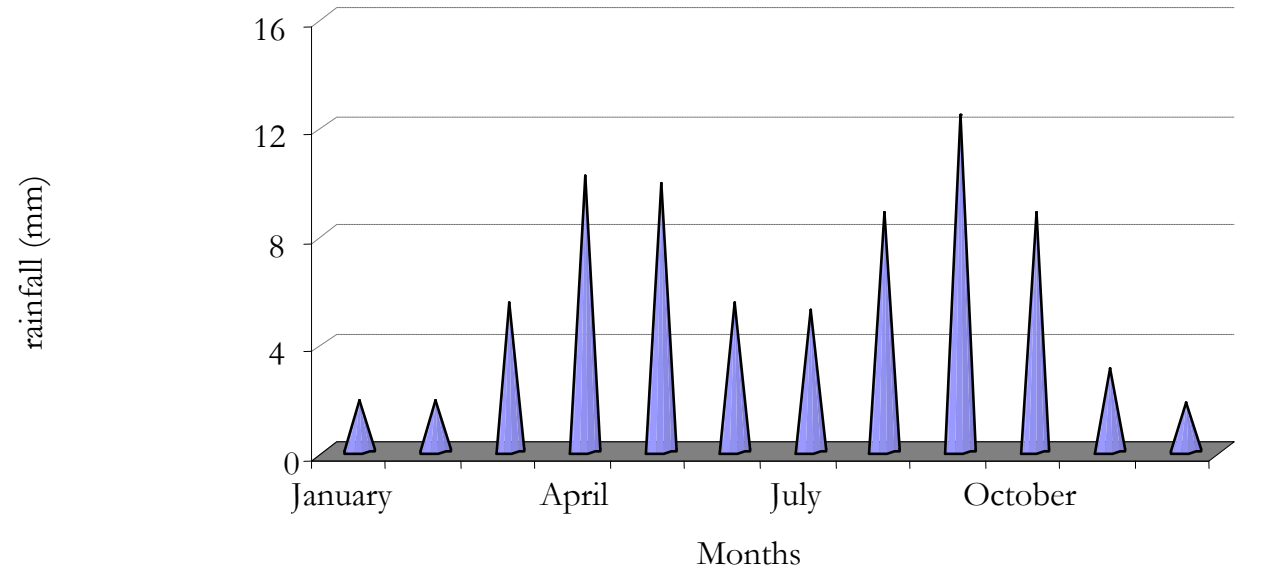

Figure 3. Monthly average (1990-2006) rainfall (mm) at the Sinana Agricultural Research Center.

\section{Acknowledgment}

The Burkard 7-days volumetric spore trap machine was purchased by aid from The International Center of Agricultural Research in the Dry Areas (ICARDA). We gratefully acknowledge the Oromia Agricultural Research Institute (OARI) for funding the research.

\section{Reference}

Bekele, H. 2003. Short report on stripe rust and stem rust. In: Bedada, G. (ed.). BADE 2003. Bale Agricultural Development Enterprise. Proceedings of the Agronomy Workshop. Addis Ababa, Ethiopia. pp.67-78.

Bekele, H., Shambel, K. and Dereje, H. 2002. Seasonal variation in the occurrincrice of wheat stripe rust in Bale highlands. Pest Management Journal 6: 65-72.

CIMMYT (International Center for Maize and Wheat Improvement). 2005. Sounding the Alarm on Global Stem Rust. An assessment of race Ug99 in Kenya and Ethiopia and the potential for impact in neighboring regions and beyond. Prepared by the expert panel on the stem rust outbreak in Eastern Africa. CIMMYT, Mexico.

Ephrem, B., Hirut, K. and Getachew, B. 2000. Durum wheat in Ethiopia: An old crop in an ancient land. Institute of Biodiversity Conservation and Research (IBCR), Addis Ababa, Ethiopia.

Guthrie, E.J. 1966. Investigation into physiologic specialization in wheat stem rust. Information Bulletin of the Near East Wheat and Barley Improvement and Production Project 3(1): 15-20.

Haldore, H., Borlang, N.E. and Anderson, R.G. 1982. Wheat in the Third World. West View Press. Boulders, Colorado, USA.

Leppik, E.E. 1970. Gene centers of plants as a source of disease resistance. Annual Review Phytopathology 8: 323344.

Mamluk, O.F., El-Daoudi, Y.H., Bekele, E., Solh, M.B., Ahmed, M.S., Mahir, M.A. and Bahamish, H.S. 2000.
Wheat Leaf and Stem Rusts in the Nile Valley and Red iea Region. ICARDA/NVRSRP, Cairo, Egypt.

Mulugeta, N. 1986. Estimates of phenotypic diversity and breeding potential of Ethiopian wheats. Hereditas 1()4: 41-48.

Naod, B. 2004. Resistance sources and variation among Ethiopian cultivated tetraploid wheats (Triticum duritm and $T$. dicoccum) to stem rust (Puccinia graminis f.sp.tritici) infection. MSc Thesis, Alemaya University, Ethiopia.

Naod, B., Fininsa, C. and Ayele, B. 2007. Sources of resistance to stem rust (Puccinia graminis f.sp.tritici) in Ethiopian tetraploid wheat accessions. Genitic Resources and Crop Evolutions 54: 337-343.

Peterson, D.P. 2001. Stem Rust of Wheat from Ancient Enemy to the Modern Foe. The American Phytopathological Society. APS Press. St. Paul, Minnesota, USA.

Peterson, R.F., Campbell, A.B. and Hannah, A.E. 1949. A diagrammatic scale for estimating rust intensity on leaves and stems of cereals. Canadian Journal of Research 26: 496-500.

Porceddu, E. and Perrino, P. 1973. Wheat in Ethiopia: Preliminary report of a collection mission. Plant Genetic Resources Newsletter 30: 33-36.

Rees, R.G. 1971. Urediospore movement and observation on the epidemiology of wheat rusts in North-Eastern Australia. Australian Journal Agricultural Research 23: 215-23.

Roelfs, A.P. 1985. Epidemiology in North America. In: Roelfs, A.P. and Bushnell, W.R. (eds.) The Cereal Rusts Vol. II; Diseases, Distribution, Epidemiology and Control. Academic Press, Orlando. pp.403-434.

Saari, E.E. and Prescott, J.M. 1985. World distribution in relation to economic losses. In: Roelfs, A.P. and Bushnell, W.R. (eds.). The Cereal Rusts Vol. II; Diseases, Distribution, Epidemiology, and Control. Academic Press, Orlando. pp.259-298.

Sewalem, A., Woubit, D. and Yesh, A. 2000. Stability of stem rust resistance in some Ethiopian Durum wheat varieties. In: Proceedings of the Eleventh Regional 
Wheat Workshop for Eastern, Central and Southern Africa. 18-22 September 2000. CIMMY'T, Addis Ababa, Ethiopia. pp.164-168

Shaw, M. 1963. The physiology and host parasite relations of the rusts. Annual Review Phytopathology 1: 259-293.

SARC (Sinana Agricultural Research Center). 2006. Plant Pathology Progress Reports for the Years 2001 to 2006.

Singh, R.P., Huerta-Espino, J. and Roelfs, A.P. 2002. The wheat rusts. In: Curtis, B.C., Rajaram, S., Gomez, H. and Macpherson (eds.). Bread Wheat Improvement and Production. Food and Agriculture Organization (FAO) of the United Nations. Rome, Italy.
Sorokina, G., Gorshkov, A. and Madumarov, T. 1980. Working out methods to enable an improvement in resistance of cereals to the major fungal disease. Scientific Phytopathological Laboratory, Progress Report for the Period 1978. Ambo, Ethiopia.

Zerihun, K. and Abdella, O. S. 2000. Host range of wheat stem rust in Ethiopia. In: Proceedings of the Eleventh Regional Wheat Workshop for Eastern, Central and Southern Africa. 18-22 September 2000. Addis Ababa, Ethiopia. pp.160-163.

Van Ginkil, M., Getinet, G. and Tesfaye, T. 1989. Stripe, stem and leaf rust in some major wheat producing areas of Ethiopia in 1987. LAR Newsletter of Agricultural Research 3 (4): 6-8. 